ОСОБИСТІСНИЙ РОЗВИТОК ПЕРСОНАЛУ ЯК ФАКТОР ПІДВИЩЕННЯ КОНКУРЕНТОСПРОМОЖНОСТІ КОМПАНІЙ У СФЕРІ ПОСЛУГ

\title{
STAFF PERSONAL DEVELOPMENT AS A FACTOR IN INCREASING THE COMPETITIVENESS OF THE SERVICE COMPANIES
}

УДК 1.159 .9

DOI https://doi.org/10.32843/2663-

5208.2020.18.1.16

\section{Прошукало І.л.}

організаційний психолог,

аспірант кафедри психології управління

Університет менеджменту освіти

Національної академії педагогічних

наук України

\begin{abstract}
у статті розглянуто питання особистісного розвитку персоналу, його впливу на підвищення конкурентоспроможності компаній у сфрері послуг. Розкрито поняття «особистісний розвиток», його критерії порівняно з поняттями «гармонійний розвиток особистості», «просресійний розвиток особистості», загалом уточнено поняття «особистість». Виділено та розглянуто специсрічні характеристики сфрери послуг, такі як невідчутність, непостійність якості послуг та неможливість зберегти послугу, щоби потім їі використати. Виділено ще одну характерну ознаку сервісних організації, а саме клієнтоорієнтованість як спеціальну активність, яка забезпечує вивчення, аналіз та задоволення потреб клієнтів i сприяє підвищенню прибутковості та конкурентоспроможності компанії. Уточнено поняття «клієнтоорієнтованість компанії», яке реалізується через побудову системи управління відносинами з клієнтами сервісних організацій, та «клієнтоорієнтованість персоналу», що реалізується через розвиток трьох основних компонентів, а саме професійиного (профресійні знання, навички та вміння), соціального (соціальна поведінка, яка спрямована на задоволення потреб клієнтів) та особистісного (базові цінності працівника та його психологічні характеристики), які тісно між собою пов'язані та орієнтовані на фрормування профресійно кваліфрікованих фрахівців для роботи у срері послуе. Особистісний розвиток персоналу у сфері послуг розкривається через сприяння розвитку таких інтраперсональних характеристик, як прийняття себе, відкритість внутрішньому досвіду переживань, розуміння себе, відповідальна свобода, цілісність, динамічність, та таких інтерперсональних характеристик, як прийняття та розуміння інших, соціалізованість, творча адаптивність. Розвиток иих характеристик сприяє реалізації особистісного та соціального компонентів клієнтоорієнтованості персоналу, отже, профресійного, оскільки вони тісно пов'язані між собою.

Ключові слова: клієнтоорієнтованість, сфера послуг, особистісний розвиток, інтерперсональність, інтраперсональність.
\end{abstract}

The article discusses the issues of staff personal development, the impact of this factor on improving the competitiveness of the service companies.

The concept of "personal development", its criteria in comparison with the concepts of "harmonious development of personality", "professional development of personality" and in general the concept of "personality" are specified. The specific characteristics of the service sector are highlighted and considered insensitivity, the inconsistency of service quality, and the inability to save the service to use it later. There is also a characteristic feature of service organizations - customer orientation as a special activity that provides study, analysis, and satisfaction of customer needs and helps to increase the profitability and competitiveness of the company. Refined "customer orientation" concept of the company which is implemented through the construction of customer relationship management service organizations and "customer orientation" of the personnel - through the development of three main components - professional (professional knowledge, skills, and abilities), social (social behavior aimed at meeting customer needs), and personal (basic values of the employee and his psychological characteristics), which are closely related and collectively focused on the formation of professionally qualified professionals to work in the field of services. Staff personal development is revealed by promoting the development of such intrapersonal characteristics as self-acceptance, openness to inner experience, self-understanding, responsible freedom, integrity, dynamism, and interpersonal characteristics - acceptance of others, understanding of others, socialization, creative adaptability. The development of these characteristics contributes to the implementation of personal and social components of customer orientation, and therefore professional, as all three components of customer orientation - professional, social, and personal are closely related.

Key words: customer orientation, service sphere, personal development, interpersonality, intrapersonality.
Постановка проблеми. У сучасних ринкових умовах клієнт (споживач) під час вибору організації значною мірою керується не тільки якістю послуги, яку надає компанія, але й рівнем сервісу, який вона пропонує.

Компанія, яка $є$ виробником тієї чи іншої послуги, безпосередньо контактує 3 клієнтом, що вимагає від співробітників не тільки відповідного рівня освіти й підготовки, але й психологічної готовності персоналу до задоволення потреб клієнта, адже багато в чому саме від рівня професіоналізму співробітника й забезпечення ним високої якості обслуговування, індивідуального підходу до задоволення потреб споживача залежить сприйняття клієнтом якості наданої послуги, відповідно, його задоволеності й лояльності до компанії загалом, тому ефективне функціонування будь-якої організації у сфері послуг визначається ступенем розвитку персоналу, який $€$ основним капіталом і фактором конкурентоспроможності організації як з точки професійного розвитку, так і щодо особистісного розвитку персоналу. 
Аналіз останніх досліджень і публікацій. Проблема особистісного розвитку знайшла своє відображення у працях таких зарубіжних дослідників, як Е. Берн, М. Джеймс, Д. Гордон, Л. Камерон-Бендлер, Ф. Перлз, Дж. Рейнуотер. Серед дослідників близького зарубіжжя проблему самоактуалізації особистості розглядали К. Абульханова-Славська, Є. Горячева; самореалізації особистості - Л. Коростильова, Д. Леонтьєв, Р. Мамеркулова; самовдосконалення особистості - Н. Гаджиєва, Ю. Орлов; саморозвитку особистості - Г. Цукерман, Б. Мастеров.

Постановка завдання. Аналіз вітчизняної та зарубіжної наукової літератури з проблеми особистісного розвитку особистості свідчить про неоднозначність, різноманітність підходів до її вивчення, тому вона $є$ однією з актуальних проблем сучасної психології. Водночас актуальною й недостатньо дослідженою виявляється проблема особистісного розвитку персоналу в контексті діяльності компаній у сфері послуг як одного з факторів підвищення конкурентоспроможності компанії на ринку послуг, що обумовлює актуальність дослідження.

Виклад основного матеріалу дослідження. Розвиток персоналу являє собою багатогранне та складне поняття, що охоплює широке коло взаємопов'язаних психологічних, соціальних та інших проблем. З'ясування його сутності передбачає визначення змісту таких ключових понять, як «особистість», «гармонійний розвиток особистості», «професійний розвитокособистості» та «особистіснийрозвиток».

Поняття «особистість» визначається «як усталена система соціально значущих рис, що всебічно характеризують індивіда. Особистість $€$ продуктом суспільного розвитку та включення індивідів у систему соціальних відношень шляхом активної предметної діяльності і спілкування. Формування особистості відбувається в процесах соціалізації індивідуумів та спрямованого виховання, опанування ними соціальних норм і функцій за допомогою оволодіння різними видами і формами діяльності» [5, с. 152].

В. Савченко визначає гармонійний розвиток особистості як «різнобічний процес набуття та вдосконалення фізичних, психологічних, моральних і економічних якостей особистості в ї розмірності, злагодженому поєднанні й органічній єдності. Гармонійний розвиток особистості означає всебічний розвиток людини як створіння соціального, яке володіє свідомістю (розумом), активного та здібного до результативної і продуктивної праці», а професійний розвиток особистості «як підготовку та адаптацію особи до роботи за конкретною професією чи спеціальністю. Професійний розвиток особистості відображає процес підготовки людини до конкретного виду трудової діяльності, включає оволодіння особистістю потрібних теоретичних знань, умінь та практичних навичок, соціальних норм поведінки» [3, с. 16].

Особистісний розвиток - це позитивні зміни в особистості через активізацію її потенціалу, а також процес набуття нею абсолютно нового досвіду, формування певного стилю поведінки та ставлення до оточуючих, що допомагає особистості впоратися з багатьма труднощами, зокрема психологічними.

Варто відзначити, що вперше феномен особистісного розвитку був представлений у межах гуманістичної концепції К. Роджерса і А. Маслоу, де було зазначено, що внутрішня природа особистості дорослої людини розкривається через самоактуалізацію, є біологічно обумовленою та забезпечується «ростом зсередини", отже, важливо, щоб соціальні умови суспільства не заважали цьому розвитку. Водночас креативні сторони особистості проявляються яскравіше, якщо вона перебуває у сприятливому оточенні та докладає відповідних активних зусиль у напрямі реалізації власної природи [4, с. 294-296].

Головний сенс особистісного розвитку, як зазначають С. Братченко та М. Миронова, - це «звільнення, набуття себе і свого життєвого шляху, самоактуалізація і розвиток всіх основних особистісних атрибутів. Повноцінний особистісний ріст можливий лише в тому випадку, якщо інтраперсональність не буде придушуватися інтерперсональністью» [1, с. 38-46]. Отже, повноцінний особистісний розвиток можливий тільки тоді, коли буде гармонійний зв'язок між інтраперсональністю та інтерперсональністю.

Також цими дослідникам на основі робіт К. Роджерса були виділені критерії особистісного росту, а саме інтраперсональні критерії, такі як прийняття себе, відкритість внутрішньому досвіду переживань, розуміння себе, відповідальна свобода, цілісність, динамічність, та інтерперсональні критерії, такі як прийняття інших, розуміння інших, соціалізованість, творча адаптивність [1, с. 38-46].

Час, необхідний для повноцінного особистісного розвитку, може бути різним і насамперед залежить від бажання людини щось змінювати у своєму житті та витрачених зусиль, отже, більшість людей продовжує вдосконалюватися впродовж свого життя.

Оскільки більшість життєвого часу людина знаходиться на роботі, праця стає важливим джерелом емоцій та почуттів, тому не менш важливу роль у розвитку працівників відіграє компанія, яка через систему навчальних та розвиваючих заходів може якісно поліпшувати не тільки професійний розвиток співробітників, але й загальний розвиток, що дає можливість для особистісного зростання. 
Розвиток персоналу має бути безперервним. Навчання розвиває працівника інтелектуально, розширює кругозір, надає впевненість, а мотивація працівників, націленість на результат, розвиток комунікаційних навичок сприяють збільшенню продажів компаній у сфері послуг (сервісних організацій), як наслідок, прибутку компанії.

Варто зазначити, що сфері послуг, на відміну від інших сфер діяльності, властиві певні специфічні характеристики, якіє характерними для всієї сервісної галузі, такі як невідчутність, непостійність якості послуг та неможливість зберегти послугу, щоби потім її використати.

Невідчутність послуги означає, що ії неможливо відчути матеріально, побачити та оцінити доти, поки клієнт її не отримає, тому працівникам сервісних організацій важливо вміти правильно презентувати послугу, володіти прийомами грамотного консультування клієнта для того, щоб ця послуга була успішно реалізована.

Мінливість якості та невіддільність послуг від кваліфікації фахівців сервісних організацій висувають особливі вимоги до навчання персоналу. Працівники сервісних організацій повинні знати не тільки техніку роботи, але й психологію спілкування з людьми та психологію споживача, щоб розуміти потреби клієнта та правильно їх задовольняти.

Неможливість зберегти послугу означає, що має бути особливий механізм вирівнювання попиту та пропозиції. Послуги не можна зберігати так, як товари, тому в періоди пікового попиту важливо заздалегідь планувати, що робитиме організація у сфері послуг для того, щоб не було черг (залучати додаткових працівників з інших відділів, стимулювати звернення в інший час тощо).

Для створення конкурентних переваг нині недостатньо надавати продукцію й послуги необхідної якості, важливо встановлювати та підтримувати довгострокові відносини з клієнтами. Особливу роль у досягненні цієї мети відіграє персонал організації, оскільки саме він взаємодіє з клієнтами.

Одним 3 найважливіших факторів успішної роботи сфери обслуговування є розуміння мотивації клієнта, що виступає необхідною конкурентною умовою. Надання послуг має бути організовано й запропоновано клієнтам таким чином, щоби повністю задовольнити їх потреби та очікування. Для цього необхідно встановлювати особистий, індивідуальний підхід до клієнта, який виражається в позитивному ставленні до клієнта, а саме бажанні допомогти клієнту у вирішенні його проблеми, «бути для клієнта», бажанні працювати з людьми. Все це формує ядро клієнтоорієнтованості персоналу.

Отже, важливою ознакою для сфери послуг $€$ клієнтоорієнтованість як компанії, так і персоналу загалом.
Як зазначає Я. Гончаренко, «клієнтоорієнтованість - це спеціальна активність, яка забезпечує вивчення, аналіз та задоволення потреб клієнтів і сприяє підвищенню прибутковості та конкурентоспроможності компанії» [3, c. 95-99].

Клієнтоорієнтоваінсть компанії реалізується через побудову системи управління відносинами з клієнтами сервісних організацій, а клієнтоорієнтованість персоналу - через розвиток трьох основних компонентів, а саме професійного (професійні знання, навички та вміння), соціального (соціальна поведінка, яка спрямована на задоволення потреб клієнтів) та особистісного (базові цінності працівника та його психологічні характеристики), які тісно між собою пов'язані й в сукупності орієнтовані на формування професійно-кваліфікованих фахівців для роботи у сфері послуг.

Сьогодні посилення конкуренції в бізнесі сприяе появі нових концепцій розвитку щодо підвищення якості робочої сили, управління якістю, управління знаннями, управління ключовими професійними компетенціями, які приводять до змін у побудові взаємовідносин у сфері послуг. Це викликано переходом до обслуговуючої економіки, де ставка робиться на людину.

Управління сучасними компаніями у сфері послуг передбачає проведення певної цілеспрямованої діяльності зі створення позитивного іміджу на ринку послуг, формування відповідного організаційного середовища, затвердження нових стандартів якості обслуговування, де важливу роль відіграє персонал.

Отже, результативність праці робітників сфери послуг залежить від сукупності дій менеджменту компаній, серед яких слід назвати особистісний розвиток персоналу. Особистісний розвиток персоналу - це загальне поняття, що описує всі позитивні зміни в особистості працівника в результаті внутрішніх процесів і зовнішніх впливів.

Якщо розглядати особистісний розвиток персоналу у сфері послуг порівняно з іншими сферами, то можна виділити певну специфіку, яка полягає в тому, що для роботи фахівців сервісних організацій найбільш характерний такий тип спілкування, як «людина - людина», який накладає певні вимоги на розвиток інтраперсональних та інтерперсональних характеристик фахівців сервісних організацій, тому реалізація управління особистісним розвитком персоналу в організації у сфері послуг може відбуватися через розвиток цих характеристик працівників, які б сприяли реалізації особистісного та соціального компонентів клієнтоорієнтованості персоналу, отже, професійного, адже всі компоненти клієнтоорієнтованості персоналу (професійний, соціальний та особистісний) тісно пов'язані між собою. Цьому можуть сприяти відповідні розвиваючі тренінги, які б розкривали інтерперсональні 
та інтраперсональні характеристики працівників сервісних організацій для успішної роботи з клієнтами задля поліпшення сервісу.

Розглянемо більш детально інтраперсональні та інтерперсональні характеристики фахівців сервісних організацій в контексті згаданих раніше критеріїв особистісного росту особистості [1, с. 38-46].

Інтраперсональні характеристики.

Прийняття себе. Працівник, який приймає себе як безумовно унікальну особистість, яка має право на повагу до себе й здатна робити свій вибір позитивно, безоціночно ставиться до себе, навіть до окремих негативних фактів, має адекватну самооцінку та вирізняється емоційною стабільністю, здатний на адекватну реакцію залежно від ситуації, розсудливе схвалення рішень, об'єктивне розуміння як власної поведінки, так і поведінки інших людей. Якщо працівник не приймає чогось у клієнтах, з якими він працює, він не приймає це у собі, а це лише буде ускладнювати його роботу та призводити до конфліктних ситуацій з клієнтами. Отже, вміти прийняти себе, ставитися позитивно й турботливо до себе - означає вміти переорієнтовувати турботу із себе на довколишніх, а це є найкращою умовою для розвитку та зростання особистості працівника сервісної організації.

Відкритість внутрішнього досвіду переживань. Чим більш психологічно зрілою є особистість, тим більш вільна вона від впливу своїх психологічних захистів, здатна враховувати власні переживання, які обумовлені як внутрішнім, так і зовнішніми впливами.

Розуміння себе. Адекватна й гнучка Я-концепція, яка дає змогу бути чутливою до актуальних змін і здатна асимілювати новий досвід для зближення Я-реального і Я-ідеального, отже, отримати людині більш повні та глибокі уявлення про себе, свій актуальний стан, зокрема свої реальні переживання, бажання, думки.

Відповідальна свобода. Якщо говорити про взаємовідносини із самим собою, це означає перш за все відповідальність за своє життя, вибір тих цінностей, якими людина буде керуватися протягом свого життя і які можуть слугувати орієнтирами працівнику у роботі з клієнтами сервісної компанії. Також це незалежність від тиску зовнішніх оцінок і суджень, що дає можливість людині актуалізувати свою індивідуальність і залишатися вірною собі.

Цілісність. Найважливіший напрям особистісного зростання працівника - це інтегрованість і взаємозв'язок усіх аспектів його життя, що передбачає відповідність змісту внутрішнього світу зовнішній діяльності, зокрема професійній.

Динамічність. Особистість існує в постійному та безперервному процесі змін. У цьому полягає сенс зрілої особистості, адже зростання є способом її існування, тому важливою умовою особистісного зростання працівника у сфері послуг $є$ динамічність, гнучкість, відкритість змінам і здатність зберігати свою ідентичність, продовжувати розвиватися через вирішення різноманітних актуальних протирічіпроблем, тобто «бутипостійноурусі».

Інтерперсональні характеристики.

Прийняття інших. В інтерперсональному напрямі особистісного розвитку працівника прийняття інших людей, зокрема клієнтів з їх іншим життєвим досвідом і власною думкою на ті чи інші речі, проявляється насамперед у динаміці ставлення до інших людей. Чим більше особистість працівника зріла, тим більше він здатний до прийняття клієнтів такими, якими вони є, до поваги їх неповторності й права бути собою, визнання їх безумовною цінністю для компанії.

Прийняття клієнтів проявляється також через вербальну та невербальну комунікацію.

Розуміння інших. Зріла особистість відрізняється здатністю до адекватного, повного та диференційованого сприйняття навколишньої дійсності взагалі, особливо інших людей. Найважливіший критерій особистісного зростання - це готовність вступати в міжособистісний контакт на основі глибокого й тонкого розуміння, співпереживання, емпатії, що є важливим для фахівців сервісних організацій в роботі з клієнтами для задоволення їхніх потреб.

Соціалізованість. Особистісний ріст веде до конструктивних соціальних взаємин та здатності компетентно вирішувати міжособистісні протиріччя й жити з іншими в гармонії.

Творча адаптивність. Найважливіша якість будь-якої зрілої особистості - це готовність до зустрічі 3 різними життєвими проблемами та здатність з ними справлятися, не спрощуючи, а проявляючи творчу адаптацію до новизни конкретного моменту. Це також стосується професійної діяльності, коли співробітник сервісної компанії проявляє творчий підхід до адаптації клієнта до своєї професійної та соціальної (клієнтоорієнтованої) поведінки задля того, щоб якомога краще пізнати особистість клієнта, дізнатися про його очікування, отже, задовольнити його потреби, при цьому не забуваючи про інтереси самої компанії. В цьому полягає сутність клієнтоорієнованості, а саме в адаптації до поведінки клієнта.

Природно, що зміни в кожному з цих напрямів особистісного розвитку працівника можуть відбуватися зі своїми специфічними закономірностями, але водночас це $є$ цілісним процесом. Отже, найважливіше - це саме бажання рухатися в цьому напрямку, включаючи процес розкриття й віднаходження себе, що дає можливість людині ставати все більш вільною і відповідальною у своєму виборі, автентичною і неповторною, доброзичливою 
і відкритою до спілкування з іншими людьми, сильною й творчою у вирішенні завдань, зрештою, більш зрілою і здатною сприймати як свій внутрішній світ, так і зовнішній. Роль компанії в цьому напрямі - це підтримка, сприяння саморозвитку працівника та управління ним, ресурсне забезпечення.

Отже, основною метою особистісного розвитку персоналу з точки зору сервісної організації $€$ розвиток особистісного потенціалу працівників задля підвищення ефективності (максимізація) діяльності персоналу для реалізації поставлених організацією цілей, а також сприяння розвитку здатності працівників реагувати на внутрішні та зовнішні зміни й успішно пристосовуватися до нових умов; позитивно вирішувати протиріччя та труднощі, брати на себе відповідальність у вирішенні професійних завдань; сприяння покращенню соціально-психологічного клімату у структурних підрозділах організації, підвищення мотивації робітників до праці, їх вірність цілям і стратегічним задачам компанії.

З позиції працівників організації особистісний розвиток полягає у розвитку своїх особистісних якостей, які допомагають формувати новий стиль соціальної поведінки для успішної роботи з клієнтами компанії, а також набуття нового життєвого досвіду. Це допомагає співробітнику вирішувати проблеми, конфліктні ситуації у роботі з клієнтами, тому особистісний розвиток персоналу - це результат взаємодії потреб і вимог організації з характеристиками та інтересами конкретного працівника. Тільки в цьому випадку цей процес $є$ цілеспрямованим і результативним. Формування та вивчення особистісного потенціалу працівників сервісних організацій сприяє визначенню шляхів не тільки їх професійного зростання, але і їх клієнтоорієнтованості у роботі з клієнтами компанії, отже, підвищенню конкурентоспроможності компанії на ринку.

Сфера послуг, відображаючи і втілюючи відповідний рівень розвитку суспільства, з огляду на сучасні умови розвитку цієї сфери вимагає особливого підходу до розвитку персоналу, який міг би спиратися не тільки на професійний досвід, знання, вміння та навички, що $€$ важливим, але й на щось більше, тобто свої базові цінності. Для того щоби стати успішним, необхідно постійно займатися саморозвитком. Від особистісного розвитку залежить задоволення людини власним життям.

Професійні та особисті успіхи сприяють виникненню у людини відчуття значущості, потрібності іншим, оптимістичного бачення своєї професійної та життєвої перспективи.

Водночас постійні психологічні навантаження, наявність значної кількості стресових ситуацій, які характерні для сфери послуг, оскільки це є досвідом спілкування з клієнтами різної вікової категорії та життєвим досвідом, може сприяти розвитку синдрому емоційного вигорання у працівників сервісних організацій.

За таких обставин співробітник компанії в сфері послуг, який виведений зі стану психологічної рівноваги, навряд чи зможе ефективно працювати 3 клієнтами та задовольняти їх потреб, отже, компаніябудевтрачатиприбуток.

Звичайно, глибина та сила стресових ситуацій залежить від того, наскільки працівник болісно сприймає конкретні стресові ситуації, переживає їх, володіє навичками щодо їх вирішення, а також вікових особливостей самої особистості (Я-концепції, спонукальної сфери, інтелекту тощо), системи соціальної підтримки, історії стресогенних (таких, що породжували стрес) подій і переживань, тому важливо в процесі особистісного розвитку персоналу мати змогу навчити та розвивати у працівників сервісних організації вміння керувати своїми емоціями, адекватно сприймати прояви емоцій інших людей та реагувати на них; розвивати певні особистісні якості, які б сприяли адаптивності до стресових ситуацій та давали змогу успішно виконувати свої професійні обов'язки; сприяти розвитку соціальнихта культурних орієнтирів (ролі, відносини тощо).

Отже, особистісний розвиток персоналу $€$ еволюційно необхідним процесом та запорукою психологічного здоров'я працівників сервісних організацій, відповідно, їх психічного та фізичного здоров'я.

Висновки 3 проведеного дослідження. Практичне розуміння та застосування концепції особистісного розвитку персоналу має розглядатися компанією як комплексне розкриття потенціалу кожного співробітника, сприяти саморозвитку задля підвищення конкурентоспроможності компанії у сфері послуг.

Серед перспектив подальших досліджень автор відзначає розроблення та аналіз методів особистісного розвитку персоналу, що можуть застосовуватися українськими компаніями у сфері послуг.

\section{ЛІТЕРАТУРА:}

1. Братченко С., Миронова М. Личностный рост и его критерии. Психологчческие проблемы самореализации личности. Санкт-Петербург, 1997. С. 38-46.

2. Гончаренко Я. Основні характеристики клієнторієнтованої комерційної організації. Актуальні проблеми психології. Організаційна психологія. Економічна психологія. Соціальна психологія : збірник наукових праць Інституту психології імені Г.С. Костюка НАПН України, 2013. № 37. С. 95-99.

3. Савченко В. Управління розвитком персоналу : навчальний посібник. Київ : КНЕУ, 2002. 351 с.

4. Тавтилова Н. К проблеме личностного роста. Молодой ученый. 2012. № 10. С. 294-296.

5. Управление персоналом: энциклопедический словарь / под ред. А. Кибанова. Москва : ИНФРА-М, 1998. VIII. 